\title{
Prevalence and correlates of metabolic syndrome in pre-crisis Syria: call for current relief efforts
}

\author{
H. Ramadan', F. Naja', F.M. Fouad ${ }^{1,3}$, E. Antoun ${ }^{7}$, M. Jaffa ${ }^{1}$, R. Chaaban ${ }^{7}$, M. Haidar ${ }^{1}$, A.M. Sibai ${ }^{1}$
}

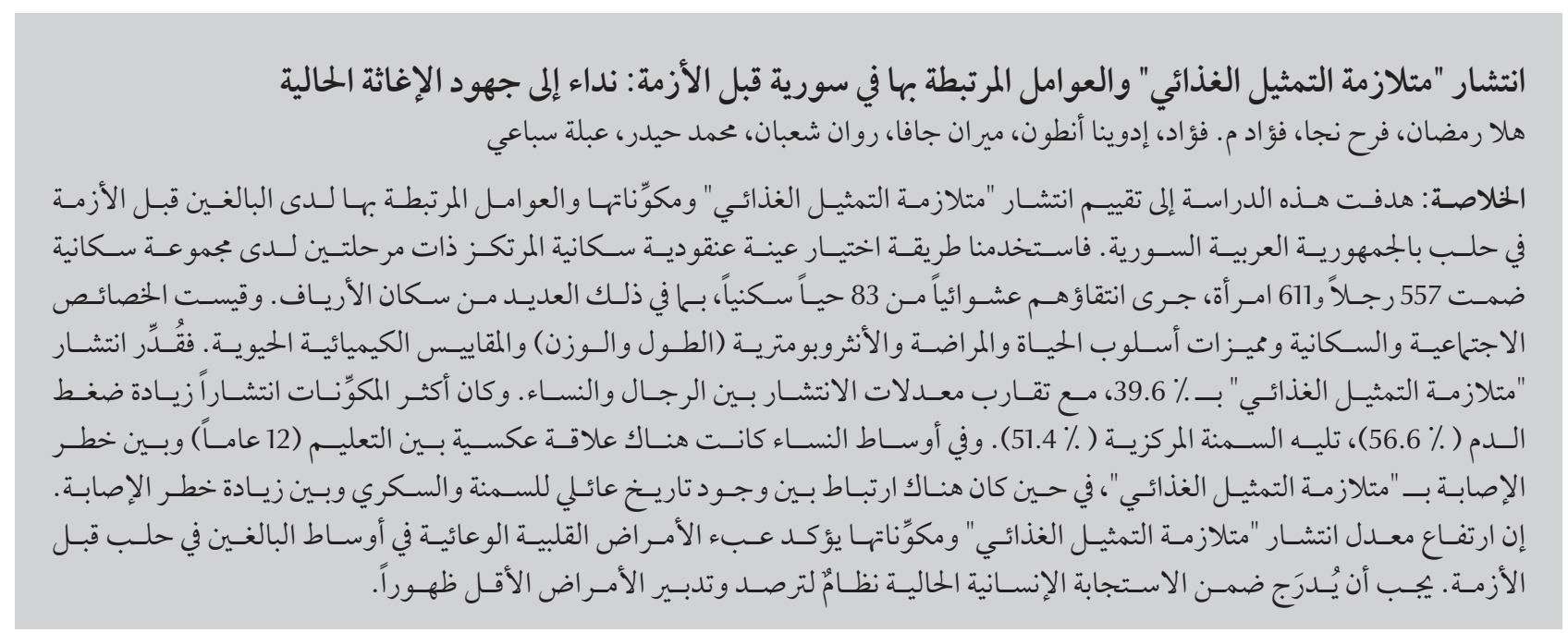

ABSTRACT This study aimed to assess the prevalence, components and correlates of metabolic syndrome (MetS) in adults in pre-crisis Aleppo, Syrian Arab Republic. We used a population-based, 2-stage cluster sampling method in a population of 557 men and 611 women, randomly selected from 83 residential neighbourhoods including many rural settlers. Sociodemographic and lifestyle characteristics, comorbidity, anthropometry and biochemical indices were measured. Prevalence of MetS was estimated at 39.6\%, with comparable rates in men and women. Hypertension was the most prevalent component (56.6\%), followed by central obesity $(51.4 \%)$. Among women, education (12 years) was inversely associated with risk of MetS, while family history of obesity and diabetes was associated with an increased risk. The high prevalence of MetS and its components emphasizes the burden of cardiovascular diseases among adults in pre-crisis Aleppo. A system of surveillance and management for cardiovascular diseases needs to be incorporated into the current humanitarian response.

\section{Prévalence et corrélats du syndrome métabolique en Syrie d'avant la crise : justification des efforts de secours actuels}

RÉSUMÉ La présente étude avait pour objectif d'évaluer la prévalence, les composantes et les corrélats du syndrome métabolique chez l'adulte à Alep avant la crise, en République arabe syrienne. Nous avons utilisé une méthode d'échantillonnage en grappe à deux degrés basée sur une population de 557 hommes et 611 femmes, choisis de manière aléatoire dans 83 zones résidentielles, comprenant de nombreux habitants de zones rurales. Les caractéristiques socio-démographiques et relatives au mode de vie, les comorbidités, l'anthropométrie et les indices biochimiques ont été évaluées. La prévalence du syndrome métabolique a été estimée à 39,6\%, avec des taux comparables entre hommes et femmes. L'hypertension était la composante la plus prévalente (56,6\%), suivie par l'obésité centrale (51,4\%). Parmi les femmes, l'éducation était inversement associée au risque de syndrome métabolique, alors que des antécédents familiaux d'obésité et de diabète étaient associés à un risque accru. La forte prévalence du syndrome métabolique et de ses composantes met en évidence la charge des maladies cardio-vasculaires chez l'adulte à Alep avant la crise. Un système de surveillance et de prise en charge des maladies cardio-vasculaires doit être incorporé à la riposte humanitaire actuelle.

'Department of Epidemiology and Population Health, Faculty of Health Sciences, American University of Beirut, Beirut, Lebanon (Correspondence to:am00@aub.edu.lb). ${ }^{2}$ Department of Nutrition and Food Science, Faculty of Agriculture and Food Sciences, American University of Beirut, Beirut, Lebanon. ${ }^{3}$ Syrian Center for Tobacco Studies, Aleppo, Syrian Arab Republic.

Received: 09/03/15; accepted: 26/07/16 


\section{Introduction}

Metabolic syndrome (MetS) refers to a cluster of physiological risk factors that identifies individuals at particularly high risk for cardiovascular disease (CVD). The International Diabetes Federation (IDF) notes that one quarter of the world population has MetS, and $~ 80 \%$ of these are at risk of death from CVDs (1). While the debate around the definition of MetS is still ongoing, a joint interim statement by the IDF, American Heart Association, and National Heart, Lung and Blood Institute in 2009 defined it as 3 or more of the following: central obesity, hypertension, elevated fasting glucose, hypertriglyceridaemia, and low high-density lipoprotein-cholesterol (HDL-C) levels (2).

High prevalence of MetS is a common trend worldwide (3). Over one third of the population in the Gulf countries has MetS (4), and recent evidence suggests an increase in dietary energy supply and rise in sedentary lifestyle, with alarming rates of obesity and diabetes, exceeding in some countries those in Europe and the United States of America (USA) (5). The present study collected data from a household survey in pre-crisis Aleppo, Syrian Arab Republic, and aimed to establish the prevalence components and correlates of MetS among the adult population. We conducted a biochemical analysis that provided an opportunity to examine MetS based on objective measures of its components.

\section{Methods}

\section{Setting and context}

Aleppo is located in the Northwest of the Syrian Arab Republic. It is the second largest city and the most populous, compromising $20 \%$ of the Syrian population of $\sim 23$ million. The first Aleppo Household Survey (AHS) was conducted in 2004 among adults aged $18-65$ years and yielded alarming prevalence rates of self-reported CVDs (45.0\%), hypertension (40.6\%) and obesity $(38.2 \%)(6,7)$. Based on such a population risk profile, Maziak and colleagues cautioned against a likely increase in morbidity and mortality from CVD, and called for more studies and reliable estimates to inform interventions and policies (6). A second AHS was conducted 2 years later by the same researchers using the World Health Organization (WHO) STEPWise approach to Surveillance (STEPS), with data collected through face-to-face interviews, anthropometric and blood pressure measurements, and assessment of blood lipid profile. The survey indicated a high level of behavioural and clinical risk factors (8). Around one third of those with type 2 diabetes were unaware of their condition, and only $16.7 \%$ of the treated cases were under control (9). In March 2011, a protracted political and civil crisis erupted in the country, resulting in severe deterioration of living conditions, and major waves of displacement and outmigration. As life-threatening injuries continue to receive higher priority in an overwhelmed health care system, treatment for chronic illnesses is becoming increasingly rare (10). Although the current study was based on data from the pre-crisis Syrian Arab Republic, the findings may be relevant to the current displaced population. The findings are also likely to shed light on the oftenoverlooked toll of noncommunicable diseases (NCDs) among refugees, and to be of use to relief agencies in planning humanitarian responses and health service needs.

\section{Study design and participants}

Data were based on secondary analyses of the cross-sectional population-based second AHS conducted in 2006 by the Syrian Center for Tobacco Studies (SCTS) and the University of Aleppo (9). Briefly, a 2-stage cluster sampling method was used, and 1268 households were randomly selected from 83 residential neighbourhoods obtained from the records of the Aleppo $\mathrm{Mu}$ nicipality Office. Only 1 adult aged 25 years was selected randomly from the household roster, excluding pregnant or lactating women. Face-to-face interviews were conducted with 1168 participants who gave informed consent to enrol in the study, yielding a response rate of $92.1 \%$. There were 557 men and 611 women, with a mean age of 44.7 [standard deviation (SD 12.7)] years. Participants were also asked to attend the SCTS laboratory within the next 7 days to provide fasting blood samples for biochemical analysis. Eight hundred and six participants consented and gave fasting blood samples (69.0\%). The study protocol was approved by the Institutional Review Board of the SCTS and the University of Memphis, USA.

\section{Instruments and measures}

A questionnaire, adapted from the WHO STEPS for NCDs and their risk factors, was administered by trained interviewers, covering sociodemographic characteristics: gender, age, education, marital status and employment status. It also included questions on healthrelated characteristics: lifestyle indicators (smoking and physical activity), family history of obesity and diabetes, and medication. Smoking was defined as self-reported cigarette or water pipe smoking in the past month. Physical activity was defined as any form of leisure activity for $>30$ minutes at least 3 times perweek.

\section{Anthropometric and blood pressure measurement}

Anthropometric measurements were taken using standardized techniques and calibrated equipment. Weight was measured to the nearest $0.1 \mathrm{~kg}$ in light clothing and with bare feet or stockings. Height and waist circumference were measured to the nearest centimetre. Participants were classified as obese if their body mass index (BMI) was $\geq 30$ $\mathrm{kg} / \mathrm{m}^{2}$ and overweight if their BMI was 
$\geq 25$ and $<30 \mathrm{~kg} / \mathrm{m}^{2}$. Blood pressure was measured by averaging 2 or 3 blood pressure readings taken by a standard mercury sphygmomanometer, with participants in a seated position after 5 minutes rest.

\section{Biochemical assessment}

Fasting venous blood was collected according to the European Health Risk Monitoring Project and the WHO Multinational Monitoring of Trends and Determinants in Cardiovascular Disease project protocols. Plasma glucose and lipid profiles [total cholesterol, low-density lipoprotein-cholesterol, HDL-C and triglyceride (TG)] were tested using an automated random access analyser of clinical chemistryturbidimetry (A25; BioSystems, Barcelona, Spain).

\section{Diagnostic criteria for MetS}

MetS diagnosis was based on the definition made by the Joint Interim Statement of several major organizations (2). Participants were considered to have MetS if they had 3 or more of the following CVD risk factors: central obesity, hypertriglyceridaemia, low HDL-C, hypertension and elevated fasting blood glucose. Central obesity was defined as waist circumference $>$ $102 \mathrm{~cm}$ for men and $>88 \mathrm{~cm}$ for women according to $\mathrm{WHO}$ recommendations (2). Diagnosis of hypertriglyceridaemia was defined as TG level $>150 \mathrm{mg} / \mathrm{dL}$ or being on medication for elevated TG. Reduced HDL-C was defined as $<40 \mathrm{mg} / \mathrm{dL}$ for men and $<50 \mathrm{mg} / \mathrm{dL}$ for women or being on drug treatment for reduced HDL-C. Participants were considered to have hypertension if they were taking antihypertensive medication or had systolic blood pressure > $130 \mathrm{mmHg}$ or diastolic blood pressure $>85 \mathrm{mmHg}$. They were considered to have elevated fasting blood glucose if they were on medication for elevated glucose or had fasting plasma glucose > $100 \mathrm{mg} / \mathrm{dL}$.

\section{Statistical analysis}

Frequencies and means (SD) were used to describe sociodemographic and health-related variables. Mean values of the various components of MetS and the proportions of the population at risk were also calculated. All data are presented for the whole sample and for men and women separately. Gender differences in baseline characteristics and prevalence rates of MetS and its components were examined using $x^{2}$ and independent-samples $t$ tests for categorical and continuous variables, respectively. Multivariable logistic regression analysis was carried out, with MetS as the outcome variable and baseline sociodemographic characteristics, lifestyle variables and family history as the covariates. These included age: $(25-39,40-59$ and $\geq 60$ years); education $(<6,6-11$ and 12 years of schooling); marital status; employment status; cigarette and/or water pipe smoking; physical activity; and family history of obesity and diabetes. Logistic regression models were fitted in blocks of sociodemographic characteristics, lifestyle variables and family history of obesity and diabetes. Unadjusted and adjusted prevalence odds ratios (ORs) and $95 \%$ confidence intervals $(\mathrm{CI})$ were calculated. SPSS for Windows version 20.0 was used for all calculations, and $P$ $<0.05$ was considered significant.

\section{Results}

Baseline sociodemographic and health characteristics of the participants are shown in Table 1. Compared to men, women were significantly more likely to have lower education level; to include a higher proportion of divorced and widowed; and to be not working at the time of the survey. Women had a higher mean BMI (32.2 \pm 6.9 vs $28.6 \pm 4.8 \mathrm{~kg} /$ $\mathrm{m}^{2}$ ). Men were $\sim 3$ times more likely to be ever smokers than women were ( $73.4 \%$ vs $25.2 \%$ ) and $~ 1.5$ times more likely to be physically active ( $12.2 \%$ vs
8.3\%). Family history of obesity was significantly higher among women than men $(45.4 \%$ vs $39.4 \%)$

Participants at risk for the various components of MetS are presented in Table 2, stratified by gender. Overall, hypertension was the most common risk factor $(56.6 \%)$, followed by central obesity (51.4\%). Elevated fasting blood glucose (33.7\%) and hypertriglyceridaemia (31.8\%) were the least prevalent. Women were significantly more likely to have central obesity than men were (65.5\% vs $36.6 \%)$. A higher proportion of men than women had reduced HDL-C (43.4\% vs $35.7 \%$ ) and hypertriglyceridaemia (38.4\% vs $25.9 \%)$. No significant gender differences were observed for hypertension and elevated fasting blood glucose. The prevalence of MetS (3 risk factors) was $39.6 \%$ overall, $38.9 \%$ in men and $40.2 \%$ in women. Close to $15.5 \%$ of the sample had none of the risk factors and $7.4 \%$ had all five.

The results of the univariate and multivariate logistic regression models that evaluated the association between the predictor variables and MetS are shown in Table 3. In the univariate analysis, age, education, marital status and employment status were associated significantly with MetS for both men and women. Family history of obesity and diabetes was associated significantly with MetS among women only. In the fully adjusted model, the prevalence odds of MetS increased with age and showed a negative trend with increasing education level among women, reaching significance when comparing 12 with $<6$ years of schooling. Family history of obesity and diabetes remained significant risk factors for MetS among women.

\section{Discussion}

This study is believed to be the first to explore the prevalence and correlates of MetS in the pre-crisis Syrian Arab 


\begin{tabular}{|c|c|c|c|c|c|c|c|}
\hline \multirow[t]{2}{*}{ Sociodemographic characteristics } & \multicolumn{2}{|c|}{$\begin{array}{c}\text { Total } \\
(n=1168)\end{array}$} & \multicolumn{2}{|c|}{$\begin{array}{c}\text { Men } \\
(n=557)\end{array}$} & \multicolumn{2}{|c|}{$\begin{array}{l}\text { Women } \\
(n=611)\end{array}$} & \multirow[t]{2}{*}{$P$-value* } \\
\hline & $n$ & $\%$ & $n$ & $\%$ & $n$ & $\%$ & \\
\hline Age, years, mean (SD) & \multicolumn{2}{|c|}{$44.7(12.7)$} & \multicolumn{2}{|c|}{$45.3(12.9)$} & \multicolumn{2}{|c|}{$44.2(12.6)$} & 0.131 \\
\hline $25-39$ & 442 & 37.9 & 203 & 36.5 & 239 & 39.1 & 0.557 \\
\hline $40-59$ & 549 & 47.0 & 264 & 47.5 & 285 & 46.6 & \\
\hline$\geq 60$ & 176 & 15.1 & 89 & 16.0 & 87 & 14.2 & \\
\hline \multicolumn{8}{|l|}{ Education, years } \\
\hline$<6$ & 351 & 30.1 & 127 & 22.8 & 224 & 36.7 & $<0.001$ \\
\hline $6-11$ & 509 & 43.6 & 256 & 46.0 & 253 & 41.4 & \\
\hline$\geq 12$ & 308 & 26.4 & 174 & 31.2 & 134 & 21.9 & \\
\hline \multicolumn{8}{|l|}{ Marital status } \\
\hline Single & 72 & 6.2 & 36 & 6.5 & 36 & 5.9 & $<0.001$ \\
\hline Married & 1000 & 85.6 & 511 & 91.7 & 489 & 80.0 & \\
\hline Divorced/widowed & 96 & 8.2 & 10 & 1.8 & 86 & 14.0 & \\
\hline \multicolumn{8}{|l|}{ Employment status } \\
\hline Not working & 624 & 53.4 & 116 & 20.8 & 508 & 83.1 & $<0.001$ \\
\hline Working & 544 & 46.6 & 441 & 79.2 & 103 & 16.9 & \\
\hline \multicolumn{8}{|l|}{ Health characteristics } \\
\hline $\mathrm{BMI}, \mathrm{kg} / \mathrm{m} 2$, mean $(\mathrm{SD})$ & \multicolumn{2}{|c|}{$30.4(6.3)$} & \multicolumn{2}{|c|}{$28.6(4.8)$} & \multicolumn{2}{|c|}{$32.2(6.9)$} & $<0.001$ \\
\hline Normal & 215 & 19.1 & 132 & 24.0 & 83 & 14.4 & $<0.001$ \\
\hline Overweight & 374 & 33.2 & 216 & 39.3 & 158 & 27.3 & \\
\hline Obese & 538 & 47.7 & 201 & 36.6 & 337 & 58.3 & \\
\hline Mean waist circumference, $\mathrm{cm}(S D)$ & \multicolumn{2}{|c|}{$97.1(13.9)$} & \multicolumn{2}{|c|}{$98.5(12.7)$} & \multicolumn{2}{|c|}{$95.8(14.8)$} & $<0.001$ \\
\hline Mean SBP, mmHg(SD) & \multicolumn{2}{|c|}{$133.3(20.4)$} & \multicolumn{2}{|c|}{$134.3(19.6)$} & \multicolumn{2}{|c|}{$132.3(21.1)$} & 0.089 \\
\hline Mean DBP, mmHg (SD) & \multicolumn{2}{|c|}{$81.8(12.6)$} & \multicolumn{2}{|c|}{$81.8(12.7)$} & \multicolumn{2}{|c|}{$81.9(12.4)$} & 0.955 \\
\hline Smoking (\% ever) & 563 & 48.2 & 409 & 73.4 & 154 & 25.2 & $<0.001$ \\
\hline Physical activity (\% yes) & 119 & 10.2 & 68 & 12.2 & 51 & 8.3 & 0.009 \\
\hline Family history of obesity (\% yes) & 495 & 42.5 & 218 & 39.4 & 277 & 45.4 & 0.037 \\
\hline Family history of diabetes (\% yes) & 479 & 41.0 & 225 & 40.4 & 254 & 41.6 & 0.683 \\
\hline
\end{tabular}

*Significance based on $x^{2}$ and independent-samples t tests, for categorical and continuous variables, respectively. $B M I=$ body mass index; $D B P=$ diastolic blood pressure; $S B P=$ systolic blood pressure $; D=$ standard deviation .

Republic. Prevalence of MetS was examined in relation to baseline sociodemographic characteristics, behaviour, and family history of obesity and diabetes. Around $40 \%$ of adults aged $\geq$ 25 years had MetS, with no significant gender difference in prevalence. Hypertension and central obesity were the main factors contributing to the MetS burden. Education and family history of obesity and diabetes were significantly associated with MetS among women.

A review of the prevalence of MetS in the neighbouring countries of Turkey and Lebanon, as well as the Gulf countries of Bahrain, Kuwait, Oman, Saudi Arabia, Qatar and United Arab Emirates, demonstrated comparable prevalence rates of $36.3-39.6 \%$ for men and 36.1-45.9\% for women (4, $11,12)$. These figures are also comparable to those estimated from western and more industrialized countries, with a prevalence of $38.9 \%$ in France and $43.4 \%$ in Greece $(13,14)$. Results have varied in Russia, with a disproportionately low figure of $18.9 \%$ in Arkhangelsk according to the IDF definition (15) and $34.7 \%$ in Moscow according to the Adult Treatment Panel III definition
(16). The prevalence rate of MetS in our study needs to be contextualized within the circumstances in Aleppo at the time of the survey, which was conducted a few years before the current conflict erupted. Aleppo was once considered a centre for international trade and manufacture and the major contributor to the Syrian agricultural economy, which made it one of the richest cities in the country. Globalization had influenced it strongly, causing major economic shifts. With the increase in free trade in Aleppo, high-energy diets and processed food became increasingly available to the 


\begin{tabular}{|c|c|c|c|c|c|c|c|}
\hline \multirow[t]{2}{*}{ Metabolic syndrome indices } & \multicolumn{2}{|c|}{ Total } & \multicolumn{2}{|c|}{ Men } & \multicolumn{2}{|c|}{ Women } & \multirow[t]{2}{*}{$P$ value* } \\
\hline & $n$ & $\%$ & $n$ & $\%$ & $n$ & $\%$ & \\
\hline Hypertension & 661 & 56.6 & 322 & 57.8 & 339 & 55.5 & 0.423 \\
\hline Central obesity & 582 & 51.4 & 202 & 36.6 & 380 & 65.5 & $<0.001$ \\
\hline Reduced HDL-C & 460 & 39.4 & 242 & 43.4 & 218 & 35.7 & 0.007 \\
\hline Elevated glucose & 394 & 33.7 & 194 & 34.8 & 200 & 32.7 & 0.449 \\
\hline Hypertriglyceridaemia & 372 & 31.8 & 214 & 38.4 & 158 & 25.9 & $<0.001$ \\
\hline \multicolumn{8}{|l|}{ Number of indices } \\
\hline 0 & 176 & 15.5 & 89 & 16.1 & 87 & 15.0 & 0.910 \\
\hline 1 & 261 & 23.1 & 128 & 23.2 & 133 & 22.9 & \\
\hline 2 & 247 & 21.8 & 120 & 21.7 & 127 & 21.9 & \\
\hline 3 & 207 & 18.3 & 105 & 19.0 & 102 & 17.6 & \\
\hline 4 & 157 & 13.9 & 71 & 12.9 & 86 & 14.8 & \\
\hline 5 & 84 & 7.4 & 39 & 7.1 & 45 & 7.8 & \\
\hline Metabolic syndrome ${ }^{a}$ & 448 & 39.6 & 215 & 38.9 & 233 & 40.2 & 0.674 \\
\hline (95\% confidence interval) & \multicolumn{2}{|c|}{$36.8-42.5$} & \multicolumn{2}{|c|}{$34.9-43.0$} & \multicolumn{2}{|c|}{$36.3-44.4$} & \\
\hline
\end{tabular}

*Significance based on $x^{2}$ and independent-samples t tests, for categorical and continuous variables, respectively.

${ }^{a}$ Defined according to the criteria of the Joint Interim Statement of major organizations, as having 3 of the 5 major risk factors for cardiovascular disease: central obesity, hypertriglyceridaemia, reduced high-density lipoprotein-cholesterol, hypertension, and elevated glucose.

once-agricultural economies, replacing traditional diets and reducing concerns of food shortages (7). As elsewhere, this nutritional transition and introduction of western dietary patterns to agricultural economies have been mostly associated with increases in obesity and other risk factors and prevalence of MetS in the region. Additionally, free trade policy has triggered the entry and promotion of foreign tobacco products, reflecting strongly on smoking rates in Aleppo, notably among men (73.4\%) (17), which may have increased certain components of MetS such as hypertension. Such factors constituting the "causes of causes" have been similarly established in recent studies from the region, showing alarmingly high prevalence rates of MetS approaching 64\% in certain urbanized high socioeconomic strata (11).

In this study, the prevalence of MetS was similar between genders (male-tofemale ratio $=0.92$ ). Comparable ratios were obtained from the USA (1.03), Europe (1.15) and the West Bank (1.0) (18-20). However, studies conducted in Turkey, Russia and Oman showed higher prevalence rates in women than in men, tracing them to the significant gender difference in prevalence of central obesity $(11,15,16,21)$. Our finding that central obesity (51.4\%) and hypertension $(56.6 \%)$ were the most contributing risk factors towards MetS concurred with other studies from the region. Obesity rates in Arab countries are high, with alarming rates already demonstrated in Kuwait (31.4\%) and Bahrain $(21.2 \%$ and $47.1 \%$ among men and women, respectively) $(22,23)$. Hypertension rates are also high in the region, notably in Morocco (70.4\%), with undiagnosed hypertension becoming a pressing public health issue $(24,25)$. We also found that women had more central obesity than men, whereas a higher proportion of men had reduced levels of HDL-C and increased levels of TG. Gender disparities in the association of several metabolic disorders with MetS have been suggested in the international literature (26). Also, genetic polymorphism contributing to dyslipidaemia has been previously identified in men but not in women (27). Furthermore, the higher smoking rates in men than women $(73.4 \%$ vs $25.2 \%)$ could have additionally contributed to the decreased plasma levels of HDL-C and increased TG in men, because of the pathogenic effect of smoking on plasma lipid profile $(28,29)$.

Covariate associations with MetS differed by gender, with family history of obesity and diabetes, and lower education level reaching significant levels among women. The link between education and MetS has been investigated in several studies in western countries, developing countries and neighbouring Gulf states; all revealing an inverse strong relationship (4,14,30-33). Education has been linked to health in 3 different ways: educated people are less likely to adopt risky health behaviours; they are more likely to be cushioned by enhanced sociopsychological resources; and they may have more rewarding jobs, higher incomes and better economic conditions; all of which are significantly associated with better health (34). Moreover, the strength of the association with family history of obesity in our study (OR $=1.60$ ) was close to that obtained in studies in other countries including the 
\%ำ

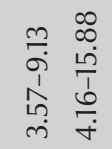
\begin{tabular}{ll}
$\infty$ & 2 \\
\multirow{1}{1}{} & 0 \\
1 & 0 \\
0 & 0 \\
0 & $\pi$ \\
0 & 0
\end{tabular}

$\begin{array}{ll}4 & 0 \\ & 0 \\ 1 & 1 \\ 1 & 1 \\ 0 & 0\end{array}$

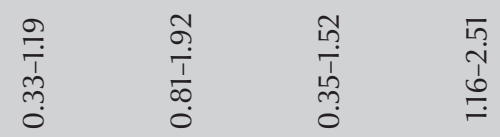

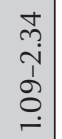

䡈

$\stackrel{\circ}{\leftarrow} \underset{\leftarrow \infty}{\infty} \frac{m}{\infty}$

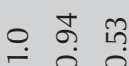

$\stackrel{0}{\circ} \stackrel{\circ}{\circ} \stackrel{1}{=}$

$\stackrel{0}{\rightarrow} \stackrel{0}{0} \stackrel{ }{ }$

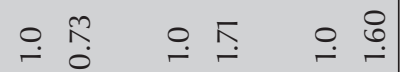

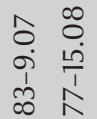

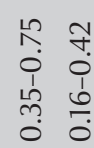

\begin{tabular}{ll}
0 & 8 \\
0 & 0 \\
0 & +1 \\
0 & 1 \\
& \multicolumn{1}{c}{}
\end{tabular}

$\begin{array}{ll}0 & \infty \\ 0 & 0 \\ 0 & 0 \\ 1 & 1 \\ 1 & 0 \\ 0 & 0\end{array}$

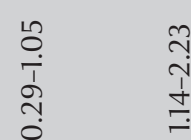

กิ?

$\stackrel{\circ}{\circ} \stackrel{\infty}{\infty} \stackrel{\infty}{\circ} \stackrel{\infty}{\infty}$

우 ถูก

$\stackrel{-}{-} \underset{1}{2} \stackrel{n}{\llcorner}$

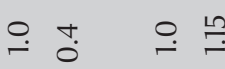

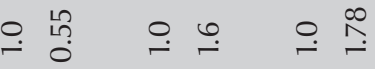

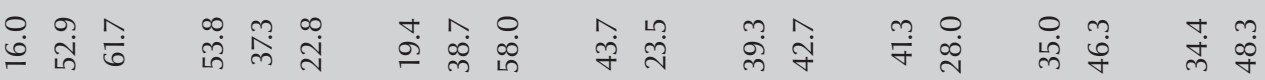

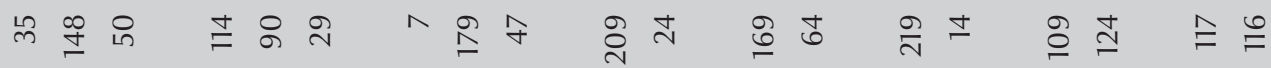

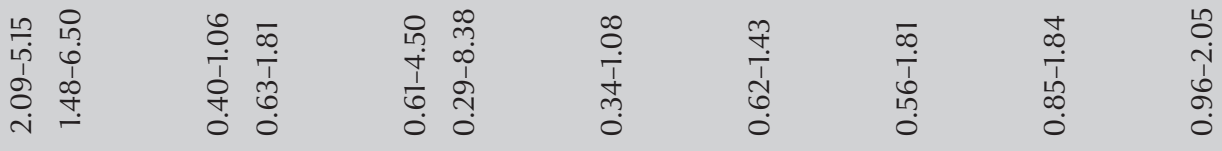

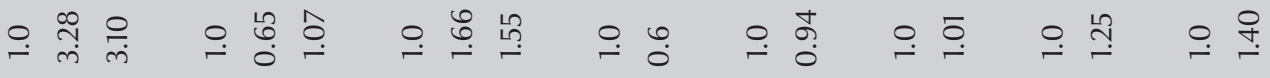

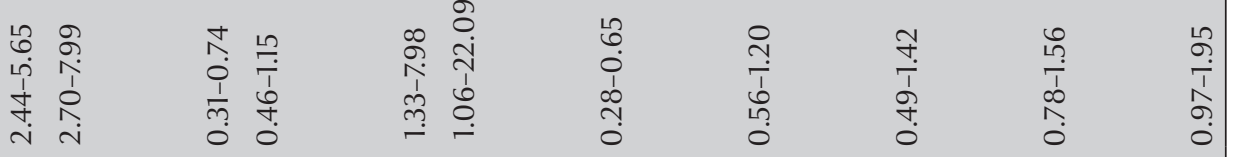

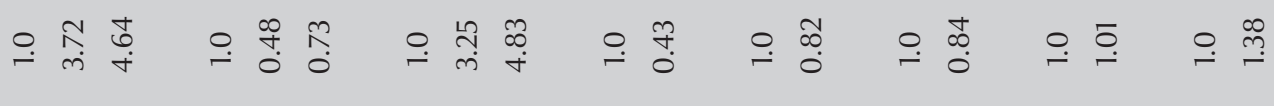

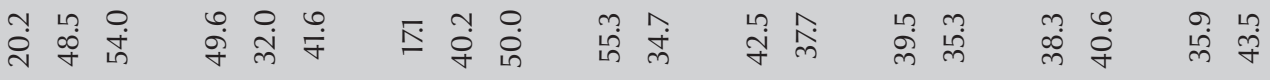

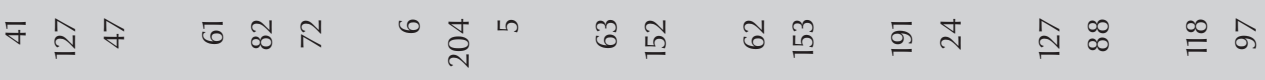

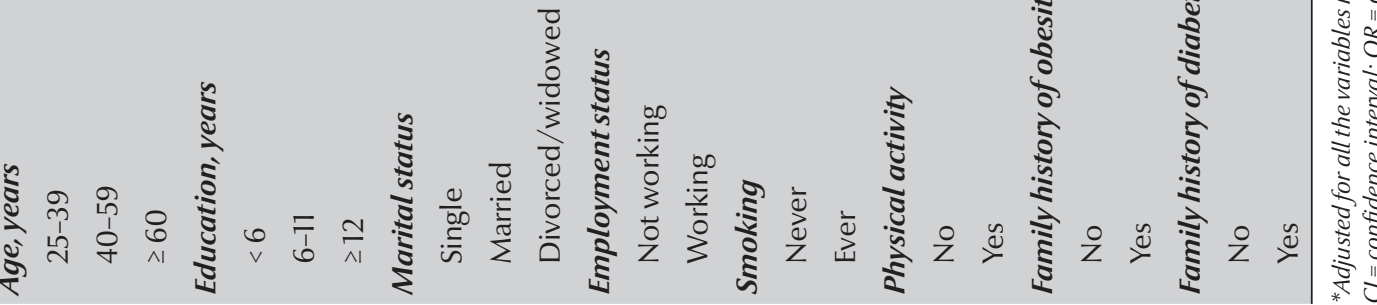


United Kingdom of Great Britain and Northern Ireland (2.0 for men and 2.7 for women), Sweden (2.7 for women) and Republic of Korea (1.22-2.64, for various female birth cohorts between 1904-45 and 1963-76) (31-33). This association was not fully explained by baseline socioeconomic characteristics and behavioural risk factors, suggesting the existence of other unstudied genetic-related mediators (32).

The findings of our study need to be considered in light of some limitations and offsetting strengths. The crosssectional nature of the study means that the temporality of certain associations cannot be established with confidence. However, this should not be regarded as a limitation for the association between education or family history and MetS because such exposures had certainly occurred prior to the outcome of interest. Although the study was conducted in a largely urbanized city and it may not be possible to generalize the findings to the rural population in the Syrian Arab Republic, the study did include the informal neighbourhoods that were formed by many of the rural settlers. Finally, the lack of an association between education and MetS among men may have been limited by the use of a single indicator to represent socioeconomic status. This might have failed to capture the complexity of the social gradient in health outcomes, including the potential role of wealth as an effect modifier interacting with education on the casual pathway to MetS (35). In spite of the above limitations, this study is one of the few in the region in which the covariates relied on objective biochemical and anthropometric measures, yielding more valid estimates than surveys relying on reported morbidity.

In conclusion, our findings point to the high levels of hypertension and obesity and consequently of MetS in pre-crisis Aleppo. They also shed light on the less visible NCD-related health needs of the Syrian adult population, when access to health care and chronic disease medication is becoming increasingly scarce. The currently overburdened healthcare system, political insecurity and ongoing fighting will limit potential interventions in the near future. Nevertheless, our survey underlines the importance of screening for CVD risk factors among the displaced populations and refugees within the Syrian Arab Republic and its neighbouring countries. Unfortunately, relief agencies in the region continue to focus their humanitarian efforts on maternal and child health, infectious diseases and sanitation, and have until today overlooked the needs of older adults and the burden of pre-existing NCDs on individuals and families struggling with mundane livelihood and security concerns. Health professionals need to raise awareness and direct attention of relief agencies to create a system of screening for CVD risk factors and management of CVDs within their humanitarian response.

Funding: The Syrian Center for Tobacco Studies is supported by grants from the National Institute on Drug Abuse (NIDA; R01DA024876-01) and Fogarty International Center (TW05962). The original field work was further supported by ASIA Pharmaceuticals (Aleppo, Syria), Medichem Middle East Company (Aleppo, Syria), and the University of Aleppo (Aleppo, Syria).

Competing interests: None declared.

\section{References}

1. International Diabetes Federation. IDF worldwide definition of metabolic syndrome. 2005 (http://www.idf.org/metabolic-syndrome, accessed 3 March 2012).

2. Alberti KG, Eckel RH, Grundy SM, Zimmet PZ, Cleeman JI, Donato KA, et al. Harmonizing the metabolic syndrome a joint interim statement of the international diabetes federation task force on epidemiology and prevention; National Heart, Lung, and Blood Institute; American Heart Association; World Heart Federation; International Atherosclerosis Society; and International Association for the Study of Obesity. Circulation. 2009 Oct 20;120(16):1640-5. PMID:19805654

3. Grundy SM. Metabolic syndrome pandemic. Arterioscler Thromb Vasc Biol. 2008 Apr;28(4):629-36. PMID:18174459

4. Mabry RM, Reeves MM, Eakin EG, Owen N. Gender differences in prevalence of the metabolic syndrome in Gulf Cooperation Council Countries: a systematic review. Diabet Med. 2010 May;27(5):593-7. PMID:20536958

5. Mehio Sibai A, Nasreddine L, Mokdad AH, Adra N, Tabet M, Hwalla N. Nutrition transition and cardiovascular disease risk factors in Middle East and North Africa countries: reviewing the evidence. Ann Nutr Metab. 2010;57(3-4):193-203. PMID:21088386
6. Maziak W, Rastam S, Mzayek F, Ward KD, Eissenberg T, Keil U. Cardiovascular health among adults in Syria: a model from developing countries. Ann Epidemiol. 2007 Sep;17(9):713-20. PMID:17553700

7. Fouad M, Rastam S, Ward K, Maziak W. Prevalence of obesity and its associated factors in Aleppo, Syria. Prev Control. 2006 Jun;2(2):85-94. PMID:18040524

8. Al Ali R, Rastam S, Fouad FM, Mzayek F, Maziak W. Modifiable cardiovascular risk factors among adults in Aleppo, Syria. Int J Public Health. 2011 Dec;56(6):653-62. PMID:21814848

9. Albache N, Al Ali R, Rastam S, Fouad FM, Mzayek F, Maziak W. Epidemiology of Type 2 diabetes mellitus in Aleppo, Syria. J Diabetes. 2010 Jun;2(2):85-91. PMID:20923489

10. Coutts A, Fouad FM. Response to Syria's health crisis - poor and uncoordinated. Lancet. 2013 Jun 29;381(9885):2242-3. PMID:23819155

11. Gundogan K, Bayram F, Gedik V, Kaya A, Karaman A, Demir O, et al. Metabolic syndrome prevalence according to ATP III and IDF criteria and related factors in Turkish adults. Arch Med Sci. 2013 Apr 20;9(2):243-53. PMID:23671434

12. Sibai A, Obeid O, Batal M, Adra N, El Khoury D, Hwalla N. Prevalence and correlates of metabolic syndrome in an adult Lebanese population. CVD Prev Control. 2008;3:83-90. 
13. Bataille V, Perret B, Dallongeville J, Arveiler D, Yarnell J, Ducimetière $\mathrm{P}$, et al. Metabolic syndrome and coronary heart disease risk in a population-based study of middle-aged men from France and Northern Ireland. A nested case-control study from the PRIME cohort. Diabetes Metab. 2006 Nov;32(5 Pt 1):475-9. PMID:17110903

14. Athyros VG, Ganotakis ES, Bathianaki M, Monedas I, Goudevenos IA, Papageorgiou AA, et al.; MetS-Greece Collaborative Group. Awareness, treatment and control of the metabolic syndrome and its components: a multicentre Greek study. Hellenic J Cardiol. 2005 Nov-Dec;46(6):380-6. PMID:16422124

15. Sidorenkov O, Nilssen O, Brenn T, Martiushov S, Arkhipovsky VL, Grjibovski AM. Prevalence of the metabolic syndrome and its components in Northwest Russia: the Arkhangelsk study. BMC Public Health. 2010 01 19;10:23. PMID:20085638

16. Metelskaya VA, Shkolnikova MA, Shalnova SA, Andreev EM, Deev AD, Jdanov DA, et al. Prevalence, components, and correlates of metabolic syndrome (MetS) among elderly Muscovites. Arch Gerontol Geriatr. 2012 Sep-Oct;55(2):231-7. PMID:21955584

17. Maziak W. Smoking in Syria: profile of a developing Arab country. Int J Tuberc Lung Dis. 2002 Mar;6(3):183-91. PMID:11934135

18. Ford ES, Giles WH, Dietz WH. Prevalence of the metabolic syndrome among US adults: findings from the third National Health and Nutrition Examination Survey. JAMA. 2002 Jan 16;287(3):356-9. PMID:11790215

19. Hu G, Qiao Q, Tuomilehto J, Balkau B, Borch-Johnsen K, Pyorala K; DECODE Study Group. Prevalence of the metabolic syndrome and its relation to all-cause and cardiovascular mortality in nondiabetic European men and women. Arch Intern Med. 2004 May 24;164(10):1066-76. PMID:15159263

20. Abdul-Rahim HF, Husseini A, Bjertness E, Giacaman R, Gordon $\mathrm{NH}$, Jervell J. The metabolic syndrome in the West Bank population: an urban-rural comparison. Diabetes Care. 2001 Feb;24(2):275-9. PMID:11213878

21. Al-Lawati JA, Mohammed AJ, Al-Hinai HQ, Jousilahti P. Prevalence of the metabolic syndrome among Omani adults. Diabetes Care. 2003 Jun;26(6):1781-5. PMID:12766109

22. Al-Kandari YY. Prevalence of obesity in Kuwait and its relation to sociocultural variables. Obes Rev. 2006 May;7(2):147-54 PMID:16629871

23. Musaiger AO, Al-Mannai MA. Weight, height, body mass index and prevalence of obesity among the adult population in Bahrain. Ann Hum Biol. 2001 May-Jun;28(3):346-50. PMID:11393341

24. Berraho M, El Achhab Y, Benslimane A, El Rhazi K, Chikri M, Nejjari C. Hypertension and type 2 diabetes: a cross-sectional study in Morocco (EPIDIAM Study). Pan Afr Med J. 2012;11:5260. PMID:22593788

25. Bcheraoui CE, Memish ZA, Toufaha M, Daoud F, Robinson M Jaber $\mathrm{S}$, et al. Hypertension and its associated risk factors in the Kingdom of Saudi Arabia, 2013: a national survey. Int J Hypertens. 2014 (http://dx.doi.org/10.1155/2014/564679).

26. Dallongeville J, Cottel D, Arveiler D, Tauber JP, Bingham A, Wagner A, et al. The association of metabolic disorders with the metabolic syndrome is different in men and women. Ann Nutr Metab. 2004;48(1):43-50. PMID:14646340

27. Phillips CM, Goumidi L, Bertrais S, Field MR, McManus R, Hercberg $S$, et al. Gene-nutrient interactions and gender may modulate the association between ApoA1 and ApoB gene polymorphisms and metabolic syndrome risk. Atherosclerosis. 2011 Feb;214(2):408-14. PMID:21122859

28. Frati AC, Iniestra F, Ariza CR. Acute effect of cigarette smoking on glucose tolerance and other cardiovascular risk factors. Diabetes Care. 1996 Feb;19(2):112-8. PMID:8718429

29. Yu M, Xu CX, Zhu HH, Hu RY, Zhang J, Wang H, et al. Associations of cigarette smoking and alcohol consumption with metabolic syndrome in a male Chinese population: a crosssectional study. J Epidemiol. 2014;24(5):361-9. PMID:24910131

30. Ford ES, Li C, Zhao G. Prevalence and correlates of metabolic syndrome based on a harmonious definition among adults in the US. J Diabetes. 2010 Sep;2(3):180-93. PMID:20923483

31. Langenberg C, Kuh D, Wadsworth ME, Brunner E, Hardy R. Social circumstances and education: life course origins of social inequalities in metabolic risk in a prospective national birth cohort. Am J Public Health. 2006 Dec;96(12):2216-21. PMID:17077402

32. Wamala SP, Lynch J, Horsten M, Mittleman MA, Schenck-Gustafsson K, Orth-Gomér K. Education and the metabolic syndrome in women. Diabetes Care. 1999 Dec;22(12):1999-2003. PMID:10587833

33. Kim MH, Kim MK, Choi BY, Shin YJ. Educational disparities in the metabolic syndrome in a rapidly changing society - the case of South Korea. Int J Epidemiol. 2005 Dec;34(6):1266-73. PMID:16131515

34. Ross CE, Wu C. The links between education and health. Am Sociol Rev. 1995 Oct;60(5):719-45.

35. Anti-selmi A, Chandola T, Friel S, Nouraei R, Shipley M, Marmot M. (2012). Interaction between education and household wealth on the risk of obesity in women in Egypt. Plos One, 7(6):e39507. PMID:22761807 